\title{
THE EMPOWERMENT OF THE FILM SPECTATOR: THEATRICAL ON DEMAND IN SPAIN
}

\section{Empoderamiento del espectador cinematográfico: exhibición bajo demanda en España}

Rafael Linares-Palomar and Antonio Baraybar-Fernández

Nota: Este artículo se puede leer en español en:

http://www.elprofesionaldelainformacion.com/contenidos/2017/ene/07_esp.pdf

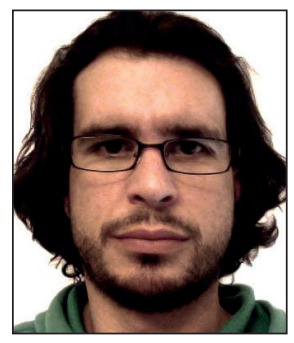

Rafael Linares-Palomar is a professor of audiovisual communication at the Rey Juan Carlos University, in Madrid. His research interests are cultural marketing, transmedia, and audiovisual production.

http://orcid.org/0000-0002-2754-2876

rafael.linares.palomar@urjc.es

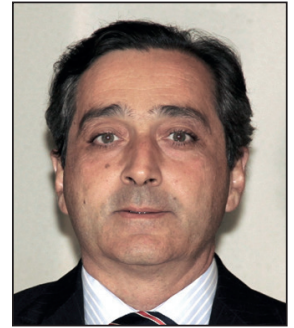

Antonio Baraybar-Fernández is a professor of audiovisual communication and advertising at the Rey Juan Carlos University, in Madrid. His research lines are related to the economy and management of communication in organizations, especially in the area of new technologies. He is the director of Francisco Villamartín Chair.

http://orcid.org/0000-0002-5474-5214

antonio.baraybar@urjc.es

Universidad Rey Juan Carlos

Departamento de Ciencias de la Comunicación y Sociología Campus de Fuenlabrada. Camino del Molino, s/n. 28943 Fuenlabrada (Madrid), España

\begin{abstract}
Thanks to the possibilities generated by digital technology a new scenario has emerged in which large groups of people are able to efficiently innovate and transform the traditional practices of companies and organizations. This article presents the results of research into the distribution and screening of films in Spain through a phenomenon known as theatrical on demand. In addition to a descriptive analysis, quantitative and qualitative data is presented to provide an evaluation of the economic, cultural, and social dimensions of this new relationship between audiences and movies. Commercial business innovation and social innovation are not separate concepts. An active society can serve as a vehicle new cultural experiences and new forms of marketing that provide access to independent productions that would otherwise be difficult to get to market through conventional distribution channels.
\end{abstract}

\section{Keywords}

Empowerment; Theatrical on demand; Independent cinema; Movie theater; On demand; Long tail; Market niches; Screenly; Youfeelm.

\section{Resumen}

Gracias a las posibilidades que genera la tecnología digital se abre un nuevo escenario donde las multitudes son capaces de innovar y transformar de forma eficaz las prácticas tradicionales de empresas y organizaciones. En este artículo presentamos los resultados de una investigación sobre el fenómeno de la distribución y exhibición cinematográfica bajo demanda en España, también conocido en el sector profesional con el término "estrenos bajo demanda" o "theatrical on demand". Además del análisis descriptivo, se aportan datos cuantitativos y cualitativos que permiten evaluar la dimensión económica, cultural y social de esta nueva forma de relación entre el espectador y la película. La innovación empresarial de carácter comercial y la innovación social no son conceptos independientes, una sociedad activa puede contribuir a nuevas formas de 
comercialización que le permitan acceder a producciones independientes de difícil difusión por los canales convencionales de distribución y vivir nuevas experiencias culturales.

\section{Palabras clave}

Empoderamiento; Estrenos bajo demanda; Cine independiente; Sala de exhibición; Distribución cinematográfica; Nichos de mercado; Screenly; Youfeelm.

Linares-Palomar, Rafael; Baraybar-Fernández, Antonio (2017). "The empowerment of the film spectators: Theatrical on demand in Spain". El profesional de la información, v. 26, n. 1, pp. 67-76.

https://doi.org/10.3145/epi.2017.ene.07

\section{Introduction}

In the current context of media and social networks, new formulas have arisen that provide the general public with the possibility of changing its traditional role as a passive receiver of products and services. This so-called digital empowerment extends to all of society as a whole and, in business terms, displaces the focus of the system from supply to demand, through the technological development of digital platforms that connect consumers.

Homo Sapiens are, above all, social animals and, unlike other animals, capable of inventing effective stories on common myths that structure people's collective imaginations and enable them to survive by facilitating cooperation and the overcoming of challenges, while the belief persists (NoahHarari, 2015). If it currently matters to be a citizen from a political, legal, social, economic, ecologic, and intercultural perspective, it also matters in media relations,

"as the communications and media dimension undoubtedly defines our times" (Gozálvez-Pérez; ContrerasPulido, 2014, p. 131).

Living in a hyper-communicated and global screen society (Lipovetsky; Serroy, 2009) means considering new possibilities for social uses by spectators in their relationship with the media. Social networks introduced radical changes in the interaction process, including:

- changes that had the capacity to create communities -in which we are able to share information and contribute to collective projects-;

- as well as to be specific -with an amazing increase in the links we are able to create- (Christakis; Fowler, 2010, p. 283).

"If there is a sector in which the transformation of power is occurring on a daily basis, everywhere and before our very eyes, that sector is the social media" (Naím, 2013, p. 317).

Technology becomes a highly powerful social tool when there are communities of users that

"incorporate it into their daily practices and use it in an innovative way. However, at the same time, we can extend the concept of social technology to incorporate new practices and new forms of production that generate new economies" (Gutiérrez-Rubí; Freire, 2013, p. 61).

The concept of empowerment integrates a proactive approach to life and a critical understanding of the social, po- litical, and economic environment. According to the World Bank, it is defined as an

"increase in the ability of individuals and groups of people to choose and transform their choices into action and the desired results" (World Bank, 2006).

One of the features of the current innovation process is the information revolution. Within this relationship between information and social change, we can identify various phases that begin with a decision to access information and concludes with the ability to act and produce personal and collective change (Gértrudix; Álvarez-García, 2014). If a person or group of people becomes empowered, they possess the ability to effectively choose (Alsop; Heinsohn, 2005). Therefore, in addition to implying access to resources, it often means exercising control over said resources by actively taking part in the decision-making process (Sathar, 1997).

Phenomena as complex and exciting as the social condition of the human being and the connection between society, technology, and empowerment that results from digitization constitutes the starting point of this work. However, it should be pointed out that this paper is mainly focused on the study of the changes that the Internet has produced in the Spanish audio-visual industry, specifically in the distribution of content to movie theaters.

\section{Status of the issue}

From a film-content production point of view, the international trend has a duality.

First, we find traditional entertainment industry productions that maintain a super-sale product creation strategy, through high levels of investment in a limited number of titles, with massive distribution to global audiences (Elberse, 2008; 2014). This situation challenges, from a financial profitability approach, the principles defended by the "long tail" economies that predicted the transformation of massive markets into a multiple market of niches, due to the abrupt reduction in production, storage, and distribution costs resulting from digitization (Anderson, 2007; 2009). As a result, forecasts of profitability and the possibility of a broader and more diversified supply have not been fulfilled. Furthermore, in the specific case of Spain, there are two significant features of the situation, amongst others, that should be highlighted:

1. The effects of the economic crisis, with a $30 \%$ reduction in investment from 2008 to 2014, the business concentration 
in the production sector, and the search for projects with international prospects (Álvarez-Monzoncillo; BaraybarFernández; López-Villanueva, 2015);

2. With respect to public investment, the current system of subsidies granted by the Institute of Audio Visual Science and Arts (Instituto de las Ciencias y Artes Audiovisuales ICAA) appears to be designed to favor major productions, a situation that increases the difficulties of developing projects with medium or small budgets in which industrial interest is not normally the priority.

http://www.mecd.gob.es/cultura-mecd/areas-cultura/cine/ el-icaa.html

Apart from films intended for mass markets, we should not overlook the existence of numerous initiatives with commercial limitations and independent production standards that also form part of our movie culture. These projects contain innovative proposals that are not based on the production, distribution systems, or processes used in the industry and go to show how

"the Internet encourages the creation and sale of products addressed to minority audiences that, considered as a whole, constitute substantial demand" (IzquierdoCastillo, 2012, p. 386).

Furthermore, the reduction of entrance barriers to technology and the possibility of communicating directly with target audiences through social networks are, amongst others, reasons that explain the arrival of the DIY (do it yourself) movement to the cinema industry and the substantial growth in this type of production. By listening to their opinion and involving viewers in the project, these permeable products encourage an active search for alternative models of production and distribution. In turn, they promote the appearance of new professional positions, such as the position of a marketing and distribution producer, that uses a $50 / 50$ rule highlighted by Jon Reiss (2010, p. 37), in which $50 \%$ of the producer's time and resources must be used for the production of the film and the remaining $50 \%$ for promotion and distribution.

The capitalist system, economic change, and access to information have resulted in a new user profile that is complex to define. In recent decades, one of the most interesting debates in the field of consumer sociology deals with the search for new types of consumers of culture, according to the new situation. The theory of distinction established by Pierre Bourdieu, the French sociologist having formulated a theory of taste based on three reference frameworks, has been questioned (Bourdieu, 1979):

- structural (social class),

- symbolic (life style), and

- habitus.

There have new proposals that are far from the traditional snobbery of the upper classes, such as

- cosmopolitanism (Hannerz, 1990),

- bourgeois and bohemian (bobos) (Brooks, 2001),

- or the more recent Homo Sampler (Fernández-Porta, 2008),

many of which belong to the new creative classes (Florida,
2009) that have taken over the middle and high class positions in the new society of information and in which the approach to cultural consumption is open and hedonistic.

The new audiences take part in the creation (crowdsourcing), funding (crowdfunding), and distribution. The Internet has enabled the creation of environments based on collaboration, which promote active unity and participation. The use of the Internet is constantly increasing and people are more dynamic in how they use this form of media, for information, learning, sharing opinions, and generating knowledge. The 2015 report on the information society in Spain, published by the Telefónica Foundation, shows that the Internet has become a universal tool and that $78.7 \%$ of Spanish people between 16 and 74 years of age use it to connect, the figure increasing to $98.5 \%$ in the 16 to 24 age group, precisely the audiences that go to movie theaters (Fundación Telefónica, 2016). However, not only has the number of users increased, but so has use itself and $89.2 \%$ acknowledged using Internet in their leisure time.

As pointed out in the Cluetrain Manifesto, the impact of the Internet has produced a change in the relations between companies and their target audiences. Communications become a bidirectional model, focused on conversation and based on the principles of dialogue, transparency, and collaboration (Levine et al., 2011).

Digitization does not make established cultural expressions such as cinema disappear, but rather transforms the way these expressions are created, produced, distributed ( $\mathrm{Za}$ Ilo, 2011) and -we could add-consumed. As a result, in this phase of convergence, it would seem advisable to analyze the new proposals of distribution with a realistic approach, in order to clarify doubts at this stage of the change. The difficulties faced by the distribution of independent titles has been a constant throughout film history and there have been numerous ways sought to reach audiences without the established marketing channels used by major studios. The creation of alternative festivals to promote this type of production and the involvement of filmmakers in projects other than those based on market logic, in areas that encourage direct contact with audiences, such as film festivals, universities, or cultural centers has always existed. The great novelty of the Internet is its possibility to establish constant and direct relations between the author and the potential audience, entirely managed through a website.

\section{Screenly and Youfeelm constitute new opportunities, although still with a limi- ted financial impact, for all the agents op- erating in the traditional film industry}

\section{Objectives and methodology}

The overall objective of this research is to examine how new forms of audio visual distribution are developing and the potential of new digital platforms that enable a change in the audience's role. Specifically, its main objective is to study theatrical on demand, as a form of film distribution in Spain, a strategy based on direct communications with 
a potential audience through Internet platforms and social networks.

We considered it to be an interesting, original and relevant proposal, given that in Spain we were unable to find relevant research about this type of film distribution. We opted for non-experimental research of a descriptive nature, given that its main purpose is to describe the phenomenon, its agents, and social and economic importance. With regard to its timeframe, the study is sectional, as it focuses on a particular time, the present.

These platforms encourage personal and group experiences, exemplifying the move to crowds connected by the same interests

The research methodology was structured into three phases: exploratory, analytic, and conclusive phases from May 2015 to July 2016, when the conclusive phase ended. The study deals with the strategies of management, organization, and performance of theatrical on demand cinema events by the companies Screenly and Youfeelm, the only platforms active in Spain at the time ${ }^{1}$.

https://screen.ly

http://www.youfeelm.com

We are aware that, although the two case studies constitute in themselves the total universe, due to the number, there are certain limitations to drawing final conclusions as to their repercussion on the sector; however, they do enable a valid approach to this incipient activity.

Two comprehensive interviews were held with the management teams of both platforms, the first during the exploratory phase and the second upon conclusion of the analytic phase. An open questionnaire was designed to determine the economic, social, and cultural aspects from a triple perspective. In order to verify the data provided by the companies, three events were chosen randomly during the investigation, thus fully confirming the accuracy of the data. At the end of the first phase, it was considered relevant to further research certain specific cases that attempted to be innovative in the subject field of the research. Once the information from external sources and primary data on the new business model was compiled, the hypotheses were determined in order to respond, amongst others, to the following questions:

- Is theatrical on demand actually an alternative formula of distribution and screening of independent productions?

- Are the new practices related to traditional forms of distribution and screening?

- Are new emotional ties generated with audiences?

It should be recalled that the

"link between technological and social change is evident, but cultural growth is not necessarily synchronized and this phase of convergence features gradual integration" (Baraybar-Fernández; Linares-Palomar, 2016, p. 141).
As a result, it was essential to design the research to combine quantitative and qualitative aspects.

- The quantitative aspects related to the number of viewers reached and the number of productions screened under the new formula.

- The qualitative aspects included those related to the impressions of the managers of the projects, by means of comprehensive interviews and an analysis of viewer conduct.

Following the detailed analysis carried out during the exploratory phase of the two platforms by an expert panel, we decided to incorporate the type proposed by María Yáñez ${ }^{2}$ into the study:

- Cult: when an author (character, saga, brand, etc.) has a relevant group of followers or fans interested in his/her work and that group can be mobilized.

- Niche: the product is targeting the interests of a previously existing community.

- Activism: when the film has a social objective.

- Hype: when there is a specific connection with something in fashion or a trend that begins to be important in society.

In short, this work can be understood as a combination of fundamental and applied aspects, between reflection and practice; although it provides a historic descriptive analysis of the projects that have driven these new relationships and businesses in our country, it also provides a classification of the audiences and content screened, based on attitude, experience, and participation from an integrated perspective of the concepts of audiences as citizens or groups of consumers (Fuente-Cobo; Martínez-Otero; Del-Prado-Flores, 2014).

Film distribution platforms within the scope of social technology are tools that enable effective coordination between large groups of people

\section{Analysis and results}

\subsection{Background}

Independent producers were the first to seek sources of finance and distribution for their films by taking advantage of the new possibilities offered by the Internet to create expectations and communities interested in a specific project. They experimented with strategies that, on occasion, reached social relevance and financial profitability. Examples include, amongst others, the following films:

\section{- The Blair Witch project (Daniel Myrick \& Eduardo Sán- chez, 1999); \\ - Four eyed monsters (Susan Buice \& Arin Crumley, 2005); \\ - Paranormal activity (Oren Peli, 2007);}

The above are success stories that, although isolated cases and unable to provide a model of stable production, were able to shed light on new approaches, establish certain guidelines, and encourage other projects. 

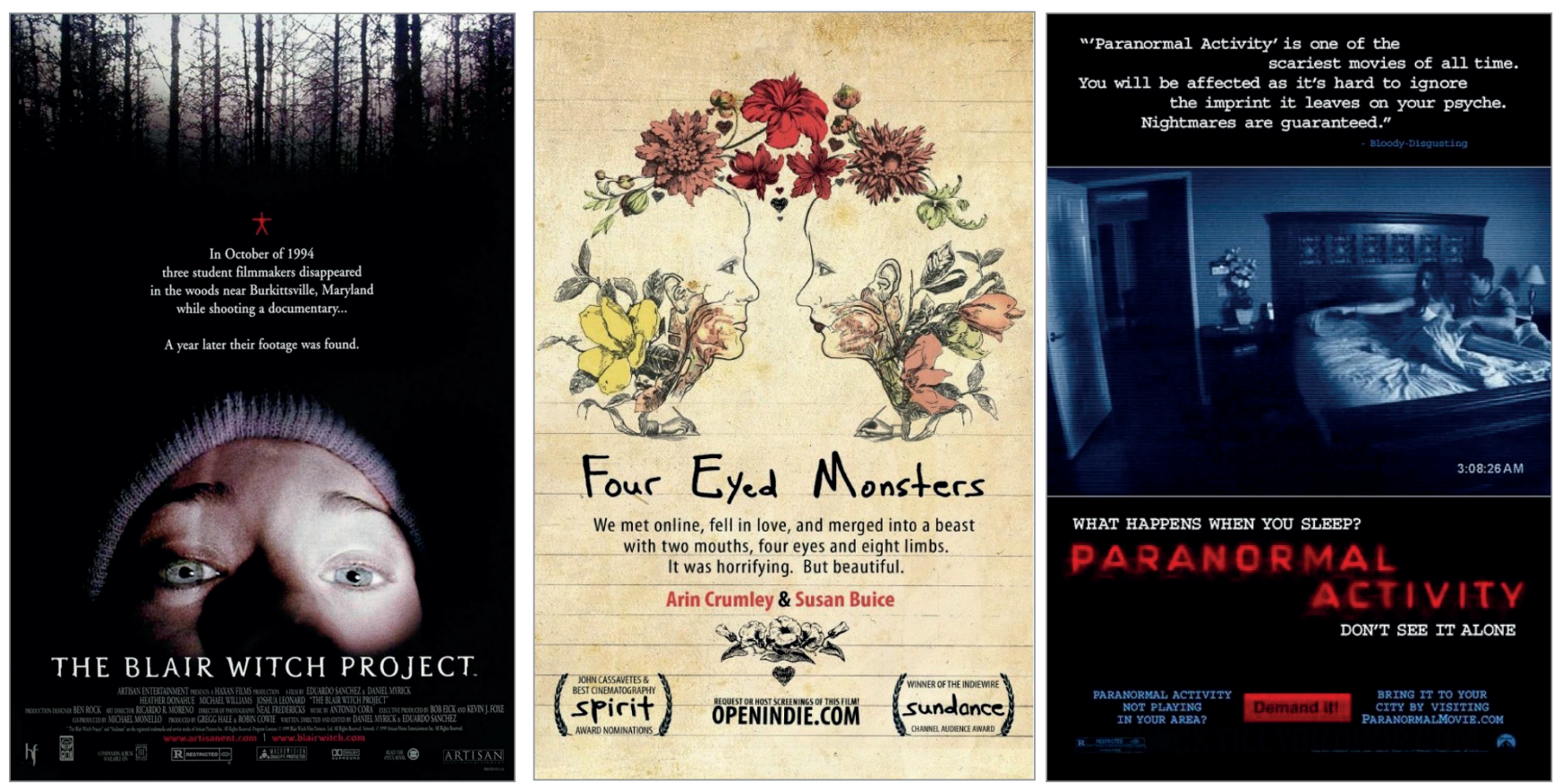

The Blair Witch project was one of the most profitable movies in the history of cinema, due to its investment and box office ratio, with a budget of $\$ 60,000$ and revenue of 248 million dollars from theatres throughout the world ${ }^{3}$. Its success was based largely on the fact that it was a pioneer in generating a viral phenomenon with a mockumentary distributed through the Syfy theme platform and its own website, in which Eduardo Sánchez helped to publicize the myth of Blair to anyone interested in receiving more information.

Four eyed monsters was capable of building an audience using online resources, a booming trend among independent contemporary North American filmmakers. It was self-distributed and allowed audiences to redistribute content and even change it according to their tastes, thus spreading it throughout the world, to become a cult film for numerous spectators, and the first film launched on YouTube.

Finally, Paranormal Activity, shot in 2007 with a budget of $\$ 15,000$ and first released in $2009^{3}$, was a pioneer in theatrical on demand. Due to the delay in its release which was a result of a dispute between the distributors Dreamworks and Paramount Pictures, the makers decided to launch a campaign on their own website and invite those interested in viewing it to vote until they achieved the necessary audience for it to be screened at a movie theatre. The active response by the community made it a success, with revenue exceeding 193 million dollars, making it another of the most profitable films in the history of cinema and the origin of an enormously popular saga that has already resulted in the release of seven films. A major distribution company therefore, somewhat incidentally, benefited from a viral publicity campaign.

In Spanish cinema we waited until 2010 for a similar case of distribution to appear, with the religious documentary $L a$ última cima (José-Manuel Cotelo, 2010), based on the life of priest Pablo Domínguez, with a limited budget. This type of project obviously has problems competing in conventional markets with major American productions with massive screening strategies that seek the highest number of spectators in the least amount of time through heavy investment in the number of copies ranging from 200 to 400 . Therefore, the makers designed a promotional campaign on their own website, by publishing several trailers of the film that mobilized a specific community by adapting to its interests and understanding its specific nature; it is important to mention the promotional material was downloaded 200,000 times. In the first week following the premiere, due to popular demand, it was scheduled for screening in $\mathbf{5 0}$ movie theaters and, in the same year, was one of the 20 most viewed films in the history of Spanish cinema ${ }^{4}$.

\section{These film distribution platforms generate a feedback process that empowers people with the freedom to choose}

In this context, theatrical on demand began to develop through platforms. One of the pioneers in the distribution of films on demand was Tugg,

https://www.tugg.com

Nicholas Gonda launched Tugg in February 2012 to address the almost nonexistent visibility of films by his friends and acquaintances in theaters, under the slogan "The movies you want at your local theater." Tugg became a simple tool for organizing requests to see films based on advanced ticket sales (Clares-Gavilán; Ripoll-Vaquer; Tognazzi-Drake, 2013).

This type of platform, which emerged in the United States due to its reduced costs and support by digital projection, became more than just a potential form of distribution of independent cinema, but rather a symbol of change in the intermediation between film makers and audiences, by allowing users to become promoters of events that were more than just leisure, but with educational and social objectives. 


\subsection{Film distribution platforms in Spain}

The first theatrical on demand distribution platforms in Spain began to emerge only a couple of years ago, i.e. 2014, inspired by Tugg. They were aimed at boosting the film distribution sector in Spain and overcoming the restrictions of a reduced industry in crisis. Two projects appeared under the brands Screenly and Youfeelm in Catalonia and Andalusia respectively, although both were obviously intended for the national market.

https://screen.ly

http://www.youfeelm.com

The practice studied in this article will redefine the space of future possibilities

Following a pilot test in Barcelona, Screenly held 68 screenings from October 2015 until May 2016, 20 of which were sold out. If we consider the 10,200 tickets sold, the average number of viewers was 150 . With two or three screenings per week, the success rate was $65 \%$. During this initial phase, agreements with movie theaters and distributors were reached; Screenly can currently screen at 51 cinemas (comprising 254 movie theaters), with 403 titles in its catalog and growing, thanks to the incorporation of 30 distributors. The promoters receive $5 \%$ of the revenue as an incentive, with time to prepare the event: ranging from a minimum of seven days to a maximum of 45 . The number of viewers required varies depending on the day of the week, movie theater or session, however it can be estimated between 50 and 150, according to the combination chosen ${ }^{5}$.

In its first year of existence, Youfeelm brought together almost 10,000 viewers for the 75 events promoted by individuals, associations, institutions, and private companies for some 25 films. This gives us an average per event of 130 people, slightly lower than that of Screenly. Youfeelm offers its services to 550 movie theaters in 72 towns throughout 38 provinces $^{6}$. It has achieved the collaboration of the Junta de Andalucía (Andalusian regional government), Telefónica, and the Cajasol Foundation and is one of the support projects for the innovation Andalucía Open Future and the program 100 Caminos al éxito (100 paths to success). The general public and communities can take part in the initiative by registering free of charge on its website. They then participate in the initiatives proposed and purchase tickets to attend, which only charge if the necessary audience for the event is eventually achieved. Its collaborative business philosophy highlights its promotion of new creators that provide their platforms free of charge for promotional purposes and to facilitate the screening of their proposals under a transparent remuneration model based on the number of viewers achieved. It is important to highlight the independent titles released in certain locations, which would almost certainly not have otherwise been possible, for example:

\section{- The tribe (Myroslav Slaboshpytskiy, 2014) \\ - the documentary La Granja del Pas (Silvia Munt, 2015).}

These two emerging projects, Screenly and Youfeelm, constitute new opportunities, although with limited financial impact, for all the agents operating in the traditional film industry: screeners, distributors, producers, and viewers.

1. They are an alternative for screeners to maximize revenue and marketing efforts at times and on days when attendance is low, mainly on Mondays and Tuesdays, without affecting possible revenue from conventional timetables.

2. They also allow distributors to maximize profits from their catalogs of films and open up a new source of revenue other than from mass distribution, concentrating on new releases; at no cost, they can benefit from "long tail" or niche economies.

Titles such as The goonies (Richard Donner, 1985) continue to be shown on both platforms successfully, despite having
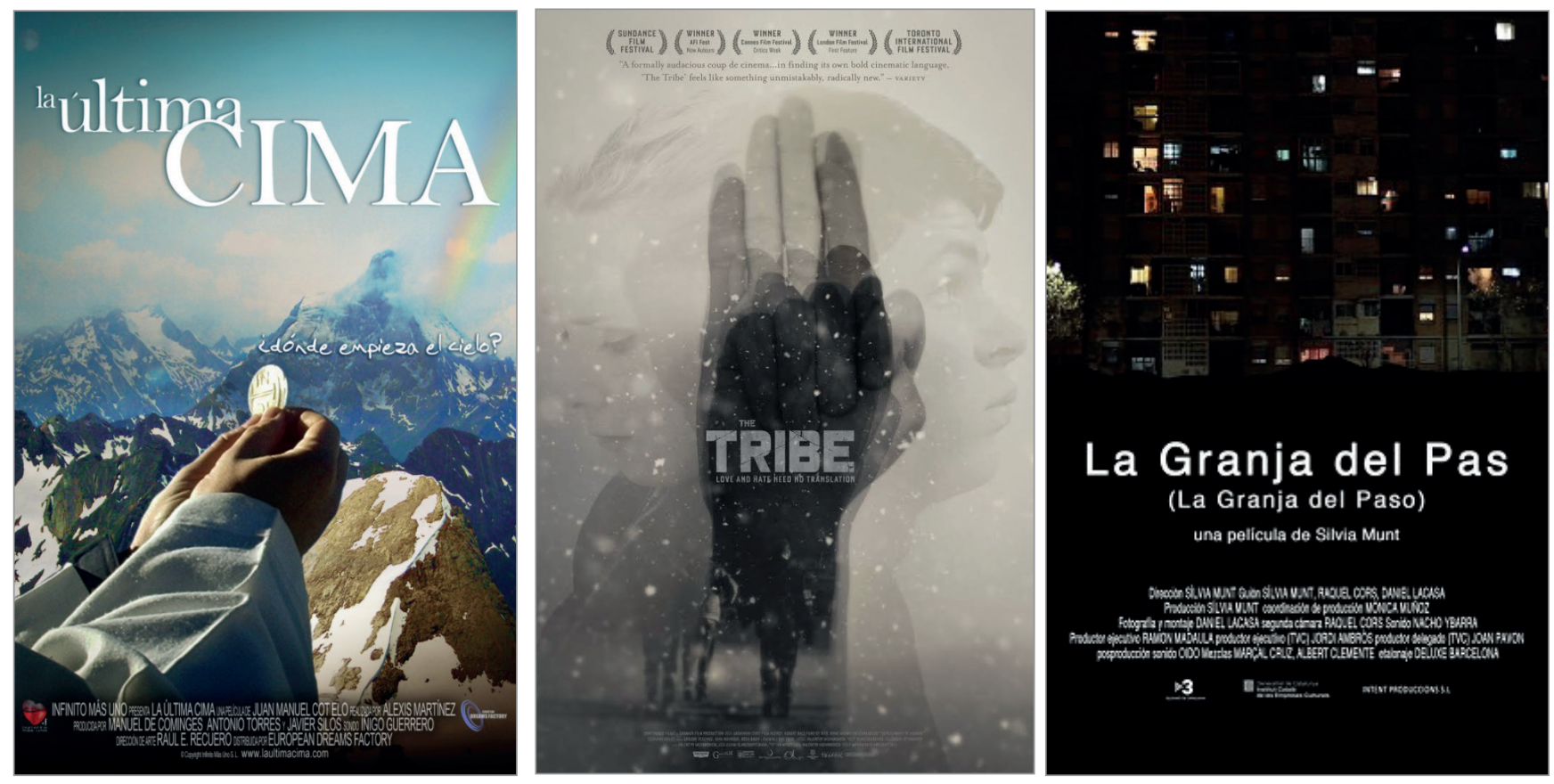


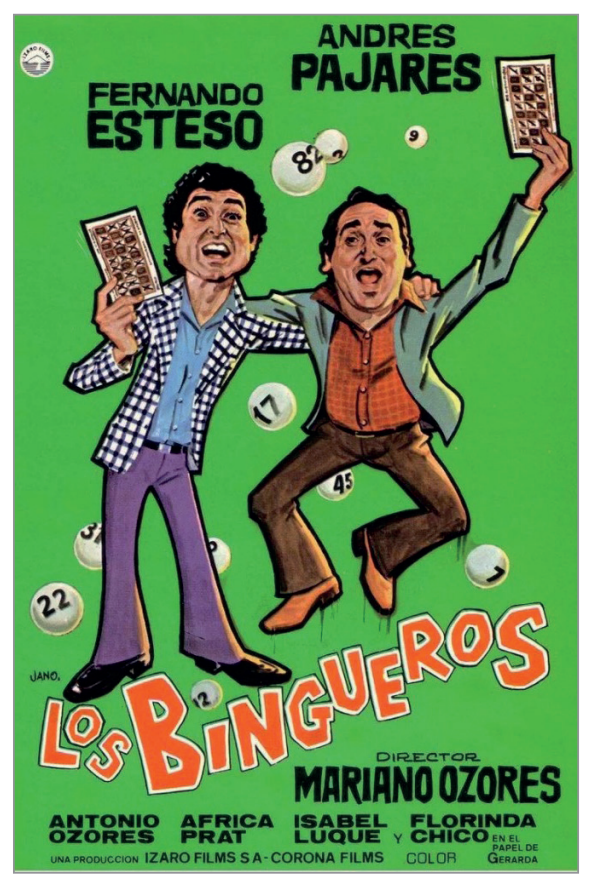
ERASERHEAD
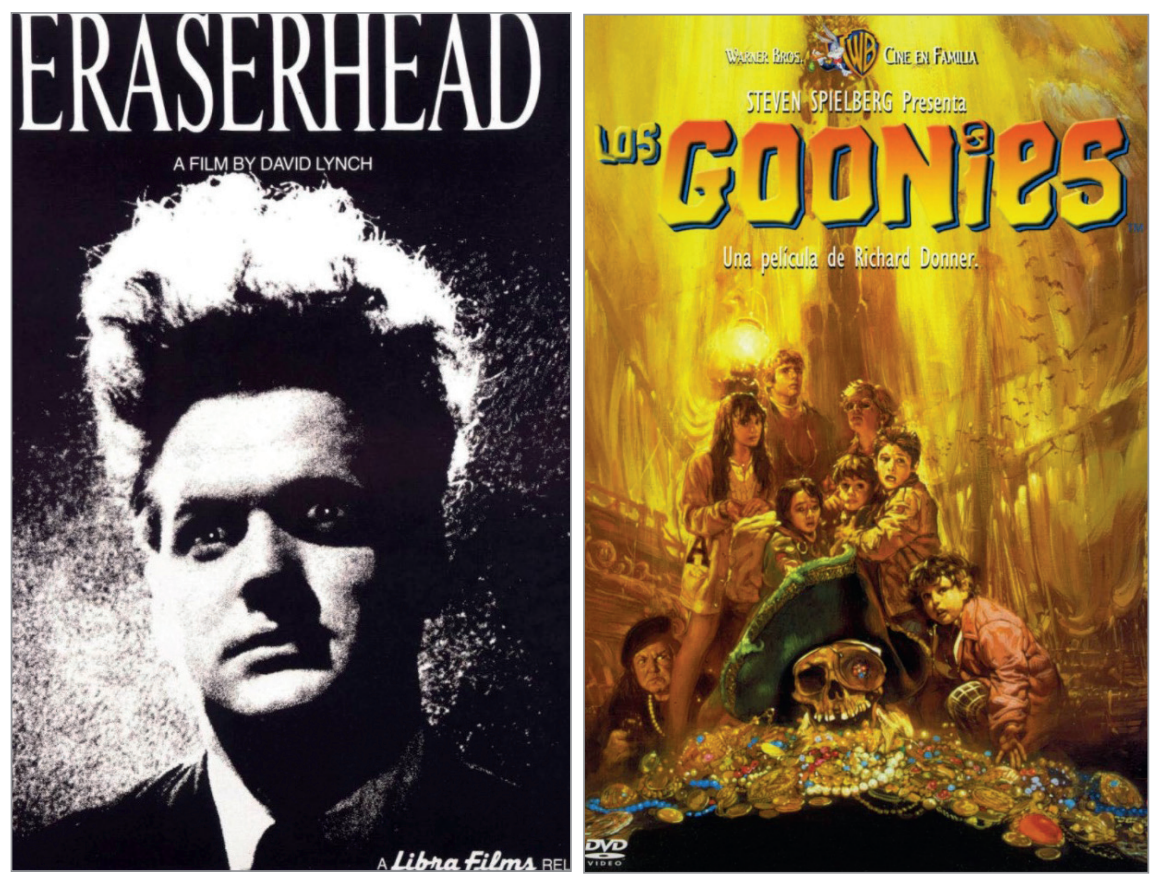

been exploited in different windows of screening; the same thing happens with auteur films such as Eraserhead (David Lynch, 1991) and Spanish comedies such as Los bingueros (The bingo players) (Mariano Ozores, 1979), producing a phenomena that is difficult to explain from a mass marketing perspective.

3. They become a variable distribution tool for independent producers, especially at a time when national production is suffering from a major contrast between high budget films and those with limited investment. Some of the titles that have been the most successful on these platforms are documentaries, which is difficult to understand from a conventional market perspective. Documentaries such as Life in flames (Manuel Martín, 2015) and Loba (Catherine Béchard, 2015) have been successful and are described in more detail below.

4. Finally, their most important feature, from a social and cultural perspective, is that theatrical on demand increases the active participation of viewers. The platforms encourage personal and group experiences exemplifying the move from masses to crowds connected by the same interests. They enable people to discover new films and support emerging filmmakers that do not have access to conventional marketing channels. They also enable viewers to influence what films are available in their city, intervene in programming, and access cultural activities that are lacking in many locations. They bring together people with similar interests that share a passion for cinema and enable them to enjoy unique personal experiences through events that have a spreading, informative, and educational effect of the specific interests of other groups.

\subsection{Successful cases}

During the research, specifically during the comprehensive interviews with the people in charge of the projects, they were asked about the most satisfying cases during their still short careers, in order to explore the strengths and opportunities generated by this new business model.

The representatives at Screenly considered its greatest success to be the distribution of the French-Spanish documentary Loba (Catherine Béchard, 2015) with a duration of 89 minutes. The film is a trip through different cultures to bring us closer to the experience of natural childbirth and reflects on the evolution of the experience of being a mother in our society and the difficulties in experiencing childbirth as a natural experience. 2,497 spectators attended the programmed events in 17 cities, nine of which were sold out, with revenue reaching $\$ 17,585.49^{7}$. The film was shown mainly in provincial capital cities, such as Palma de Mallorca, Madrid, Barcelona, Seville, Valencia, and Malaga; also in smaller cities such as Reus and Ribadeo.

\section{Financially, theatrical on demand is not a profitable enterprise}

The representatives at Youfeelm referred to important documentaries that combined conventional distribution practices, theatrical on demand, and the creation of events:

- Life in flames (Manuel Martín, 2015) which, for 78 minutes, tells the story of three elite fire fighters, was screened in 10 cities throughout Spain and was on demand in the months of September and October 2015, with 2,200 viewers;

- they were also impressed with the social issue production Línea de meta (Finish line) (Paola García Costas, 2014), which tells the story of Josele, a marathon runner who takes part in national and international events while pushing his daughter Maria, who has Rett Syndrome, in a cart in order to bring attention to research into "rare diseases" that are not profitable for pharmaceutical laboratories. 
Although it premiered in a traditional theater, the rest of its distribution was on demand in 16 cities from November to April 2016 and viewed by 1,800 people ${ }^{8}$.

In both cases, the themes are very specific, possibly unable to attract mass audiences, but of undoubted social interest for sectors of the population that are directly affected and, on occasion, already organized in communities seeking content to support their objectives and therefore willing to play an active role in promoting the films.

\section{Discussion and conclusions}

We should always take care to avoid drawing conclusions in the study of a subject in its embryonic stage. Cultural change does not always go hand in hand with technological change and it is clear that the past does not necessarily have to become a prologue in this particular sector, where new commercial channels are constantly being explored. However, we need to reflect on the idea that the practices studied in the present will redefine the scope of future possibilities. Furthermore, the two cases studied and their innovative proposals do not enable us to make final conclusions - as indicated in the methodology section -, but do represent an initial approach to a new phenomenon in Spain.

We began with the premise that digital empowerment is not exclusively limited to groups and organizations at the risk of exclusion, but rather a phenomenon that extends throughout society, as it enables people to give their opinion and interact. In this scenario, we can include film distribution platforms within the scope of social technology, as a tool that enables effective coordination between large groups of people and generates a feedback process that empowers them with the freedom to choose (Gutiérrez-Rubí; Freire, 2013, p. 110).

In response to the hypothesis proposed, theatrical on demand screenings are an alternative to conventional distribution and exhibition. Above all, it has become one of the few options for independent productions that do not have access to conventional mass-market solutions. From a financial perspective, it is not a profitable exercise that guarantees the required return on investments in the film industry, but is a new source of revenue, with virtually no costs, although evidently with marginal profits. However, its social and cultural contribution has been proven by its ability to increase and personalize supply through active audience participation. The imminence of the phenomenon studied makes it difficult to provide an accurate definition of how users will behave in relation to this new form of cultural consumption, but opens up new possibilities in the relationship
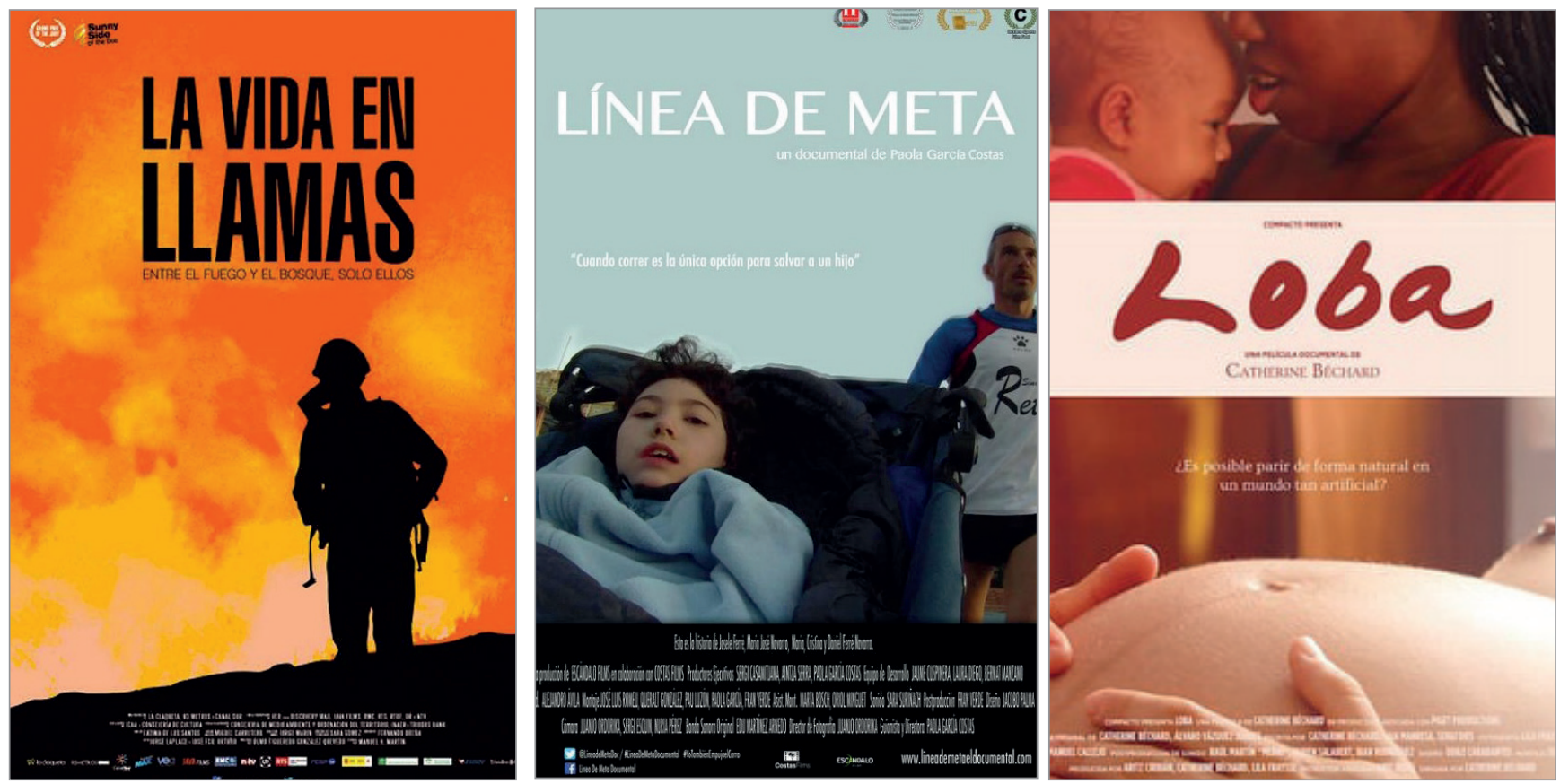
between audiences and titles. The definition of audiences adopted for this study proved to be valid for the analysis of the most relevant cases and, therefore, constitutes the backbone of the business strategy of both platforms. Theatrical on demand increases the possibilities for success when the filmmaker is important and well-known in a community, the film's content generates interest for an existing group of people, it has an obvious social objective, or is able to synchronize with an emerging social trend.

The relationship between conventional practices and this new form approach is of a complementary nature, coexistence that does not give rise to exclusion or conflict:

- the former refers to a logical exploitation of movie theaters with the greatest number of viewers in the shortest time possible, with the aim of recovering an investment and continuing sales in other screening windows, for which intensive marketing campaigns are undertaken prior to the premier;

- the latter, intended for a previously non-viable market niche, bases its communications campaign on the ability to generate a community through the Internet and social networks, which requires on-going activity over time and greater control over the message, based on the opinions and acts of the viewers themselves.

One is intended for mass audiences and the other for active groups that share needs, in which the relationships between members may be more important than the initial value proposal. Correct management of these intelligent groups empowers the community and converts its members into prosumers that add value to the project.

It also provides conventional distributors and independent producers with access to the new collaborative business culture. By possessing direct information on viewer behavior, preferences can be directly addressed and new relationships and business models explored. It enables changes in fashion or trends to be detected and, finally, common interests accelerate in the on-going improvements process.

If we generally believe that users are increasingly more demanding and autonomous, the availability of films at movie theatres will require greater personalization. The platforms subject to this study invite viewers to structure their own proposals, to achieve more as a community of consumers. Amidst apocalyptic forecasts with predictive algorithms and the use of an immense amount of our data to define the availability of culture, initiatives are also appearing on the Internet that provide citizen empowerment.

\section{Notes}

1. In the sample chosen, we decided to exclude the Veobeo platform which, despite being subsidised by the Spanish Ministry of Culture for technological development, during the timeframe of the research, no events had been scheduled.

2. María Yáñez is the director of communications at Screenly and this classification proposal appears in the presentation available at:

https://www.slideshare.net/secret/49JHrCHzqo16AB
3. Source: $h t t p: / / w w w . i m d b . c o m$

4. Source: Productora Infinito+1

5. Source: Data provided by Screenly in response to a questionnaire prepared by the authors for the study.

6. Source: Data provided by Youfeelm in response to a questionnaire prepared by the authors for the study.

7. Source: Screenly

8. Source: Youfeelm

\section{References}

Alsop, Ruth; Heinsohn, Nina (2005). Measuring empowerment in practice: Structural analysis and framing indicators. World Bank Policy Research. Working paper, February. http://siteresources.worldbank.org/INTEMPOWERMENT/ Resources/41307_wps3510.pdf

Álvarez-Monzoncillo, José-María; Baraybar-Fernández, Antonio; López-Villanueva, Javier (2015). “Audiovisual production in Spain. Fewer resources, same problems, new challenges". Economia della cultura, v. 25, n. 2, pp. 211-222. https://doi.org/10.1446/81241

Anderson, Chris (2007). La economía long tail. Barcelona: Urano. ISBN: 9788493464264

Anderson, Chris (2009). Gratis. El futuro de un precio radical. Barcelona: Tendencias. ISBN: 9788493696108

Baraybar-Fernández, Antonio; Linares-Palomar, Rafael (2016). "Nuevas propuestas de distribución audiovisual en la era de la convergencia: el documentarybook". El profesional de la información, v. 25, n. 1, pp. 135-142.

http://dx.doi.org/10.3145/epi.2016.ene.13

Bourdieu, Pierre (1979). La distinción. Madrid: Taurus. ISBN: 8430603387

https://www.academia.edu/7384950/Pierre_Bourdieu. La_distinci\%C3\%B3n._Criterio_y_bases_sociales_del_gusto

Brooks, David (2000). Bobos in paradise. The new upper class and how they got there. New York: Simon \& Schuster. ISBN: 9780684853789

Christakis, Nicholas A.; Fowler, James H. (2010). Conectados. Madrid: Taurus. ISBN: 9788430606887

Clares-Gavilán, Judith; Ripoll-Vaquer, Jaume; Tognazzi-Drake, Alberto (2013). Distribución audiovisual en internet. Vod y nuevos modelos de negocio. Barcelona: UOC. ISBN: 978 8490299111

Elberse, Annita (2008). "Should you invest in the long tail?". HBS centennial issue Harvard business review, v. 86, n. 7/8, pp. 88-96.

https://hbr.org/2008/07/should-you-invest-in-the-long-tail

Elberse, Annita (2014). Superventas. Barcelona: Gestión 2000. ISBN: 9788498753714

Fernández-Porta, Eloy (2008). Homo Sampler: tiempo y consumo en la Era Afterpop. Barcelona: Anagrama. ISBN: 978 8433962805

Florida, Richard (2009). Las ciudades creativas: por qué 
donde vives puede ser la decisión más importante de tu vida. Barcelona: Paidós. ISBN: 9788449322044

Fuente-Cobo, Carmen; Martínez-Otero, Juan-María; DelPrado-Flores, Rogelio (2014). "Las audiencias activas en la regulación de los medios: la dialéctica consumidor-ciudadano en España y México". Comunicar, v. 22, n. 43, pp. 91-99. https://doi.org/10.3916/C43-2014-09

Fundación Telefónica (2016). La sociedad de la información en España. Barcelona: Ariel; Fundación Teléfonica. ISBN: 9788408152798

http://www.fundaciontelefonica.com/arte_cultura/ publicaciones-listado/pagina-item-publicaciones/itempubli/483

Gértrudix, Manuel; Álvarez-García, Sergio (2014). “Las fases del empoderamiento". Figshare, 3 julio.

http://dx.doi.org/10.6084/m9.figshare.1092528

Gozálvez-Pérez, Vicent; Contreras-Pulido, Paloma (2014). "Empoderar a la ciudadanía mediática desde la educomunicación". Comunicar, v. 21, n. 42, pp.129-136.

https://doi.org/10.3916/C42-2014-12

Gutiérrez-Rubí, Antoni; Freire, Juan (2013). Manifiesto Crowd. La empresa y la inteligencia de las multitudes. Laboratorio de Tendencias.

http://www.manifiestocrowd.com

Hannerz, Ulf (1990). "Cosmopolitans and locals in world culture". Theory, culture and society, v. 7, n. 2, pp. 237-251. http://www.oneworlduv.com/wp-content/uploads/2011/06/ cosmopolitans_locals_culture.pdf https://doi.org/10.1177/026327690007002014

Izquierdo-Castillo, Jessica (2012). "Distribución online de contenidos audiovisuales: análisis de 3 modelos de negocio".
El profesional de la información, v. 21, n. 4, pp. 385-390. https://doi.org/10.3145/epi.2012.jul.09

Kishor, Sunita; Neitzel, Katherine (1996). "Status of women: Indicators for twenty-five countries". Demographic and health surveys comparative studies, n. 21. Calverton, Maryland: Macro International Inc.

http://dhsprogram.com/publications/publication-cs21comparative-reports.cfm

Levine, Rick; Locke, Christopher; Searls, Doc; Weinberger, David (2011). The Cluetrain Manifesto: The end of business as usual. New York: Basic Books. ISBN: 9780465018659

Lipovetsky, Gilles; Serroy, Jean (2009). La pantalla global. Cultura mediática y cine en la era hipermoderna. Barcelona: Anagrama. ISBN: 9788433962904

Naím, Moises (2013). El fin del poder. Barcelona: Debate. ISBN: 978849992300

Noah-Harari, Yuval (2015). Sapiens. De animales a dioses. Barcelona: Debate. ISBN: 9788499924212

Reiss, Jon (2010). Think outside the box office: The ultimate guide to film distribution in the digital era. New York: SCB Distribuitors. ISBN: 9780982576205

Sathar, Zeba A. (1997). Women's autonomy, livelihood \& fertility: A study of rural Punjab. Islamabad: Pakistan Institute of Development Economics.

World Bank (2006). World development report 2006: Equity and development. Washington DC. ISBN: 9780821362495

Zallo, Ramón (2011) Estructuras de la comunicación y de la cultura. Políticas para la era digital. Barcelona: Editorial Gedisa. ISBN: 9788497846653

\section{RecBib ¡Descúbrenos! 